\title{
Enumeration of Nitrates in Wainganga river water in District Bhandara (M.S.) India.
}

\author{
A.D.Bobdey \\ Department of zoology, SSES Science College, \\ Congress Nagar, Nagpur-12 \\ drad.bobdey@sscn.in
}

\begin{abstract}
:
As a result of present study of the river in district Bandara, it is concluded that, the concentration of nitrates remains maximum during summer season and moderate during winter and rainy season. In view of the various domestic activities four sampling stations have been selected for the present investigation. Maximum concentration of nitrates observed during summer season in the month of April was $8.14 \mathrm{mg} / \mathrm{L}$ at station $\mathrm{S}-4$, and $7.71 \mathrm{mg} / \mathrm{L}$ in the month of May during the next year at station S-4, While minimum values of nitrate concentration noted, $1.98 \mathrm{mg} / \mathrm{L}$ during rainy season, in the month of August at station $\mathrm{S}-1$, and $1.77 \mathrm{mg} / \mathrm{L}$ in the month of August during the next year at station S-1. The proteinaceous organic matter present in municipal sewage and other wastes, on decomposition results in to the formation of ammonia. The increased activity of nitrifying bacteria in high temperature of river water causes the increase in the values of nitrates during summer season. Due to discharge of sewage and domestic wastes and less flow of water in the river results in to the turbidity. This may influence some extent, to the photosynthetic activities and up take of nutrients by phytoplanktons.
\end{abstract}

\section{Key Words :}

River, Nitrates, Nitrites, Concentration, health

\section{Introduction:}

Water is regarded as 'polluted' when it is changed in its quality or compositions, directly or indirectly as a result of human activities, so that it becomes less suitable for drinking, as well as domestic and other purposes. As a consequence of rapidly expanding industrialization and excessive population growth, most of our rivers, lakes, streams and other water bodies are being increasingly polluted. Pollution of fresh water results largely from the waste disposal. Many of our lakes are becoming increasingly murky, smelly and choked with excessive growth of algae. Most of the rivers have become darkened with sewage, chemicals, industrial effluents and other 
undesirable foreign extraneous matter. The rivers commonly carry sewage, industrial effluents and agricultural runoff, which include fertilizers and pesticides. Moreover, the rivers carry and deposit their pollutants in to the ocean. Thus, the oceans are also polluted by toxic wastes which cause contamination of sea foods on a large-scale. Nitrate concentration of water bodies are influenced with the geochemical conditions, organic load and the rate of their mineralization. However, surface run-off during rainfall is responsible to increase the nitrate concentration in water (Narayan and Chauhan, 2000).

Nitrogen forms a major constituent $(80 \%)$ of atmosphere. It occurs in small amount in water due to low solubility of molecular nitrogen in biosynthesis. Beside this, nitrogen is also found in small amount in water in bounded forms, such as ammonia, nitrates, nitrites and organic nitrogen viz. urea, amino acids, nucleic acids etc. When nitrogenous matter get oxidized by the environment, the nitrogen remains chiefly in the form of nitrates. The presence of appreciable quantities of nitrates can be regarded as an indication of recent sewage contamination. Nitrite is readily oxidized to nitrate, and accordingly large amount of nitrate points towards the sewage contamination (Bobdey et al, 2009). Nitrate is the most highly oxidized form of nitrogen compound, commonly present in natural waters, because it is the product of nitrogenous organic matter. Significant sources of nitrate are chemical fertilizers, decayed vegetables, chemical matter, domestic effluents, sewage, sludge disposal to land, industrial discharges, and leaches from refuse dumps and atmospheric washout. Changes in land use may also give rise increase of nitrate level. Depending on the situation, these sources can contaminate streams, rivers, lakes and ground water.

Nitrates and nitrites are naturally occurring inorganic nitrogen ions, mainly occurs in soil and waters and in some foods. Consumption of water or food from the areas containing the areas of modern agricultural zone mainly of rice fields, the communities exposed to high levels of nitrogen. peoples might be exposed to nitrates and nitrites as normal parts of a human diet. Vegetables such as cauliflower, spinach, collard greens, broccoli, beets, and root vegetables have naturally greater nitrate content 
than do other plant foods, from soil and water contaminated by runoff from nitrogen-containing fertilizers, from contaminated foodstuffs, from certain medications. Nitrate $\left(\mathrm{NO}_{3}^{-}\right)$and nitrite $\left(\mathrm{NO}_{2}^{-}\right)$are inorganic ions that occur naturally and are part of the nitrogen cycle. Nitrates (e.g., potassium nitrate and ammonium nitrate) are common ingredients of fertilizer that contains nitrogen.

The most serious health condition caused by high nitrate or nitrite exposure is acute acquired methemoglobinemia. Infants younger than 4 months of age exposed to high levels of nitrates/nitrites are especially prone to acute acquired methemoglobinemia, which is described more fully in this fact sheet in the section entitled. Nitrite oxidizes easily into nitrate. Also the gradual enrichment of nutrients and development of animal and plant life in a water body is also caused by high levels of nitrates.

\section{Material and methods:}

A work plan has been conceived for the present investigation to study the water quality of "WAINGANGA RIVER". In view of the various domestic activities four sampling stations have been selected in Pauni town in Bhandara district for the present investigation. Station 'S-1' is located at the construction site of Dam at village Gosikhurd, nine kilometers away from the sampling station S-2 of Pauni town.

Besides all these sources of pollution, the decaying cowdung manure also pollutes the river water during summer. The dry regions of the river basin has been taken on lease, for farming the crops of Watermelon and Muskmelon, by some farmers during the months from February to May, The cowdung, which is used as fertilizers for these crop fields enters in the water current at stations S-2 and S-3. The fishing activities are carried at stations S-1, S-2 and S-3, the fisherman prepare artificial hiding places with the help of dry wooden branches of trees.

Samples from different sampling stations were collected for physical and chemical analysis. The sample analysis of nitrate were performed in the laboratory by titrimetric method. The weekly collection of samples of water from different spots and depths of river was done by Mayer's sampler. The 
samples were preserved by refrigeration at $4{ }^{\circ} \mathrm{C}$, in ice box for short interval of travel, which is most general accepted method. (NEERI, 1986).

\section{Result and discussion:}

From the values obtained in the month of February, March, April, and May during summer it reveals that, the Nitrate concentration in Wainganga river water ranges, from $3.15 \mathrm{mg} / \mathrm{L}$ to $3.61 \mathrm{mg} / \mathrm{L}$ at station $\mathrm{S}-1,6.81 \mathrm{mg} / \mathrm{L}$ to $7.46 \mathrm{mg} / \mathrm{L}$ at station $\mathrm{S}-2,6.72 \mathrm{mg} / \mathrm{L}$ to $7.75 \mathrm{mg} / \mathrm{L}$ at station $\mathrm{S}-3$ and $7.06 \mathrm{mg} / \mathrm{L}$ to $8.14 \mathrm{mg} / \mathrm{L}$ at station $\mathrm{S}-4$. The perusal of data reveals that, during the next year nitrate concentration varies from $3.0 \mathrm{mg} / \mathrm{L}$ to 3.41 $\mathrm{mg} / \mathrm{L}$ at station $\mathrm{S}-1,5.96 \mathrm{mg} / \mathrm{L}$ to $6.44 \mathrm{mg} / \mathrm{L}$ at station $\mathrm{S}-2,6.38 \mathrm{mg} / \mathrm{L}$ to $6.78 \mathrm{mg} / \mathrm{L}$ at station $\mathrm{S}-3$ and $6.89 \mathrm{mg} / \mathrm{L}$ to 7.71 at station S-4. During the rainy season, in the month of June, July, August and September it ranges from $1.98 \mathrm{mg} / \mathrm{L}$ to $3.98 \mathrm{mg} / \mathrm{L}$ at station $\mathrm{S}-1,3.62 \mathrm{mg} / \mathrm{L}$ to $7.30 \mathrm{mg} / \mathrm{L}$ at station $\mathrm{S}-2,3.88 \mathrm{mg} / \mathrm{L}$ to $7.59 \mathrm{mg} / \mathrm{L}$ at station $\mathrm{S}-3$ and $3.90 \mathrm{mg} / \mathrm{L}$ to 7.73 $\mathrm{mg} / \mathrm{L}$ at station $\mathrm{S}-4$. While during the next year it varies from $1.77 \mathrm{mg} / \mathrm{L}$ to $2.86 \mathrm{mg} / \mathrm{L}$ at station $\mathrm{S}-1,3.30 \mathrm{mg} / \mathrm{L}$ to $6.0 \mathrm{mg} / \mathrm{L}$ at station $\mathrm{S}-2,3.45 \mathrm{mg} / \mathrm{L}$ to $6.21 \mathrm{mg} / \mathrm{L}$ at station $\mathrm{S}-3$ and $3.61 \mathrm{mg} / \mathrm{L}$ to $6.98 \mathrm{mg} / \mathrm{L}$ at station $\mathrm{S}-4$, 4.38). During winter, in the month of October, November, December and January, nitrate concentration ranges from $2.85 \mathrm{mg} / \mathrm{L}$ to $3.11 \mathrm{mg} / \mathrm{L}$ at

station S-1, $5.87 \mathrm{mg} / \mathrm{L}$ to $6.26 \mathrm{mg} / \mathrm{L}$ at station $\mathrm{S}-2,5.98 \mathrm{mg} / \mathrm{L}$ to 6.51 at station S-3 and $6.21 \mathrm{mg} / \mathrm{L}$ to $6.88 \mathrm{mg} / \mathrm{L}$ at station S-4,. However, during next year it ranges from $2.63 \mathrm{mg} / \mathrm{L}$ to $3.10 \mathrm{mg} / \mathrm{L}$ at station $\mathrm{S}-1,5.41 \mathrm{mg} / \mathrm{L}$ to $5.89 \mathrm{mg} / \mathrm{L}$ at station $\mathrm{S}-2,5.51 \mathrm{mg} / \mathrm{L}$ to $5.99 \mathrm{mg} / \mathrm{L}$ at station $\mathrm{S}-3$ and $6.03 \mathrm{mg} / \mathrm{L}$ to $6.81 \mathrm{mg} / \mathrm{L}$ at station $\mathrm{S}-4$.

Maximum concentration of nitrates observed during summer season in the month of April was $8.14 \mathrm{mg} / \mathrm{L}$ at station $\mathrm{S}-4$, and $7.71 \mathrm{mg} / \mathrm{L}$ in the month of May during the next year at station S-4, While minimum values of nitrate concentration noted, $1.98 \mathrm{mg} / \mathrm{L}$ during rainy season, in the month of August at station S-1, and $1.77 \mathrm{mg} / \mathrm{L}$ in the month of August during the next year at station S-1.

On the basis of results recorded during the present investigation it can be concluded that, the maximum values were obtained in the summer and 
winter season. While in the rainy season, concentration of nitrates became minimum. The varying quantity of pollutants discharged in the river at different stations, which resulted in to variation in the values of nitrates. (Sharma and Pande, (1998)).

One of the most wrong in fact crazy human activities, "River basin agriculture" is responsible to hike nitrate levels in the study area. Some of the fisherman community performs agriculture of watermelon and muskmelon crops at the middle planes of river basin. However use of cow dung and pig dung manure constantly mixes in the flow of water. Upstream practices affect the water of downstream areas.

However, the catchment areas of the Wainganga river is blessed with high yielding rice fields. In modern rice crop agriculture the crops are frequently supplied with urea fertilizer for more yields. During rainy seasons runoff water carry the pure nitrogen sources in the river water, while underground seepage in post monsoon and early winter days enhance the nitrogen content of river water. Thomas et.al, (2001)., Jameel, (1998). During rainy season dilution of pollutants and wastes due more quantity of water in flooded river showed comparatively decreased levels of nitrates. Balls et.al, (1996)

The proteinaceous organic matter present in municipal sewage and other wastes, on decomposition resulted in to formation of ammonia, which further oxidized in to nitrites and nitrates. During summer, increased activities of nitrifying bacteria at high temperature of river water, causes the mineralization of ammonia and subsequently increase in the values of nitrates during summer season. The discharge of sewage and domestic wastes in less flow of river forms the turbidity to some extent, may influence the photosynthetic activities and up take of nutrients by phytoplanktons. Rath et.al, (2000), Musaddiq, (2000).

During late winter, abundance of phytoplankton population and activities of denitrifying bacteria resulted in to the lower values of nitrates. Subsequently, the relatively more quantity of water in river during the months of winter dilutes the pollutants to some extent and the decreased activities of microbes in low temperature of water are the main reasons of 
decrease in the levels of nitrates in river water. Similar changes were noted Prasanthan and Nayar, (2000) in Parvatiputhen AR. Canal, Aggrawal et.al, (2000) in river Varuna and

Excessive nitrate levels in drinking water may result $\mathrm{n}$ acute acquired methemoglobinemia a serious health condition. Hemoglobin in blood carries oxygen from the lungs to tissues and helps carry carbon dioxide back to the lungs. Hemoglobin in blood contains iron normally found in the $\mathrm{Fe}^{2+}$ (ferrous) state. But excessive nitrates or nitrites can alter the iron in hemoglobin to the $\mathrm{Fe}^{3+}$ (ferric) state. This forms methemoglobin, an abnormal form of hemoglobin. As methemoglobin forms, the blood loses its ability to carry oxygen to tissues (anoxia). (ATSDR, 2004) Methemoglobinemia is actually an excess of methemoglobin in the blood. It may cause cyanosis (blue skin) of limbs/trunk, weakness, and rapid heart rate. If methemoglobinemia progresses in severity, central nervous system depression can occur, as can headache, dizziness, fatigue, difficulty in breathing, and nausea. Excess severity can cause lethargy, brief loss of consciousness, irregular heartbeat, shock, convulsions, coma, and even death. (Nathan D.M., Siegel A.J., Bunn H.F., 1977)

The U.S. EPA has set an enforceable standard called a maximum contaminant level (MCL) for nitrates at $10 \mathrm{ppm}$ and for nitrites at $1 \mathrm{ppm}$ in drinking water. Public water supplies meeting certain criteria must follow these regulations. The U.S. EPA has set a reference dose (RfD) for nitrate of $1.6 \mathrm{mg}$ nitrate nitrogen/ $\mathrm{kg}$ body weight per day (equivalent to about $7.0 \mathrm{mg}$ nitrate ion $/ \mathrm{kg}$ body weight per day). The U.S. EPA has set an RfD of $0.1 \mathrm{mg}$ nitrite nitrogen $/ \mathrm{kg}$ body weight per day (equivalent to $0.33 \mathrm{mg}$ nitrite ion $/ \mathrm{kg}$ body weight per day).

Nitrate and nitrite medications may cause hypotension (low blood pressure). Maternal exposure to environmental nitrates and nitrites may increase the risk of pregnancy complications such as anemia, abortion, premature labor, or preeclampsia. The Department of Health and Human Services (DHHS), the International Agency for Research on Cancer (IARC), and the Environmental Protection Agency (EPA) have not classified nitrates and nitrites as to their human carcinogenicity. Still, a metabolic pathway is 
available for nitrites to react with molecules in organisms to form $\mathrm{N}$-nitroso compounds, some of which may cause cancer. Infants younger than 4 months of age are prone to nitrite exposure; especially infants who ingest formula diluted with water from nitrate-contaminated rural domestic wells. A portion of hemoglobin in young infants is still in the form of fetal hemoglobin. Nitrites can more readily generate methemoglobin from oxidized fetal hemoglobin than from adult hemoglobin. Thus, infants less than 4 months of age, and especially premature infants, are particularly susceptible to such exposure. At or near the 30th week of pregnancy, an expectant mother and her fetus might be more sensitive to toxicity from nitrites or nitrates. (ATSDR, 2007)

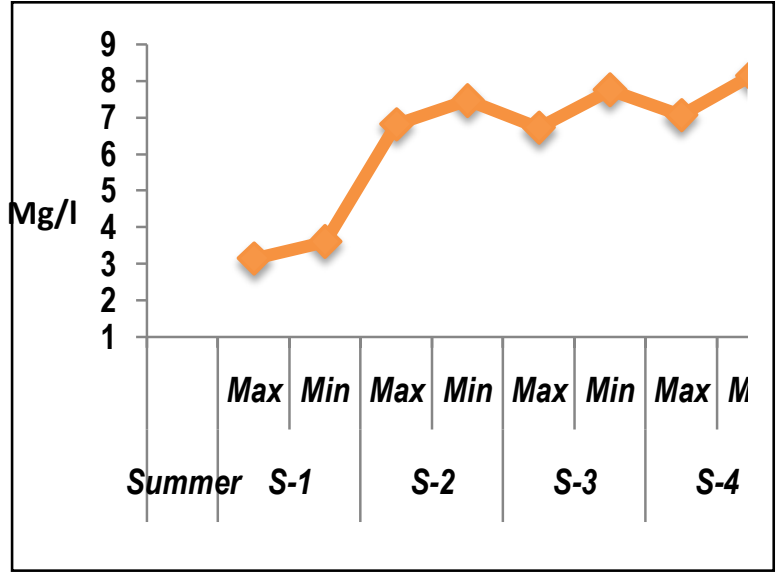

Fig-1

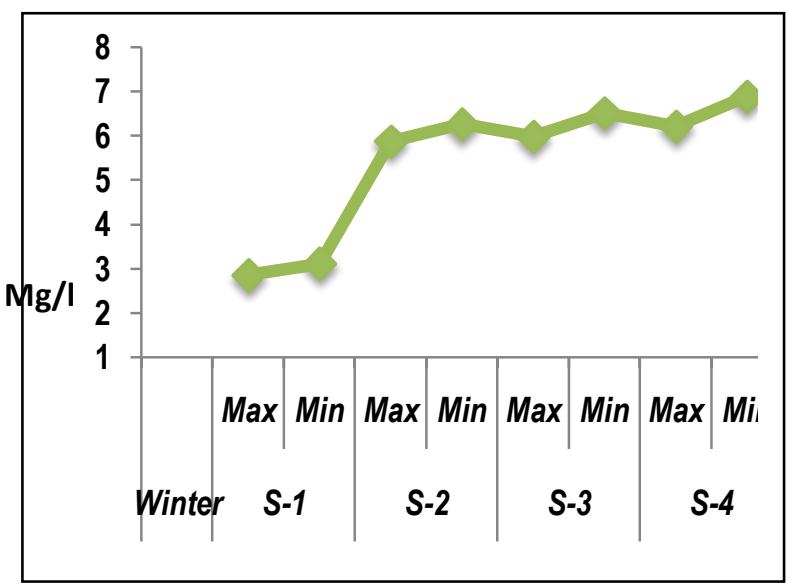

Fig-2

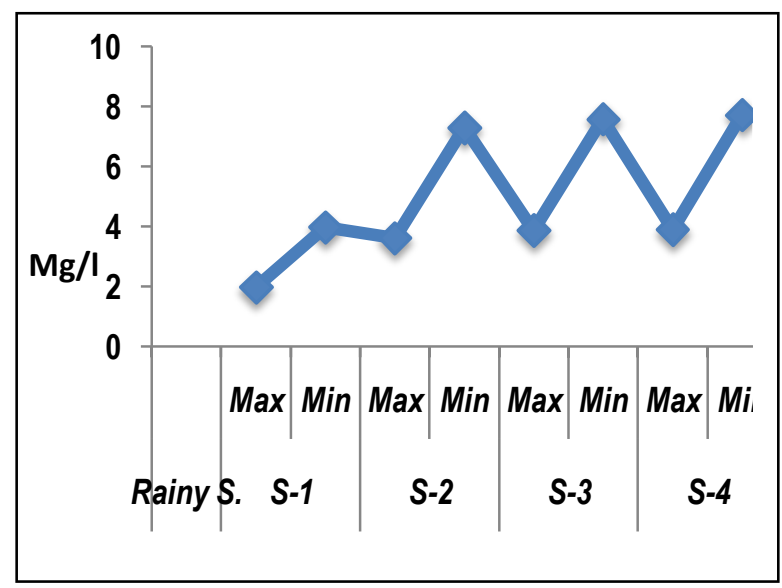

Fig-3

Fig-1, Fig-2, Fig-3 : Concentration of Nitrates (Mg/L) in wainganga River During Summer, Winter \& Rainy Seasons respectively 


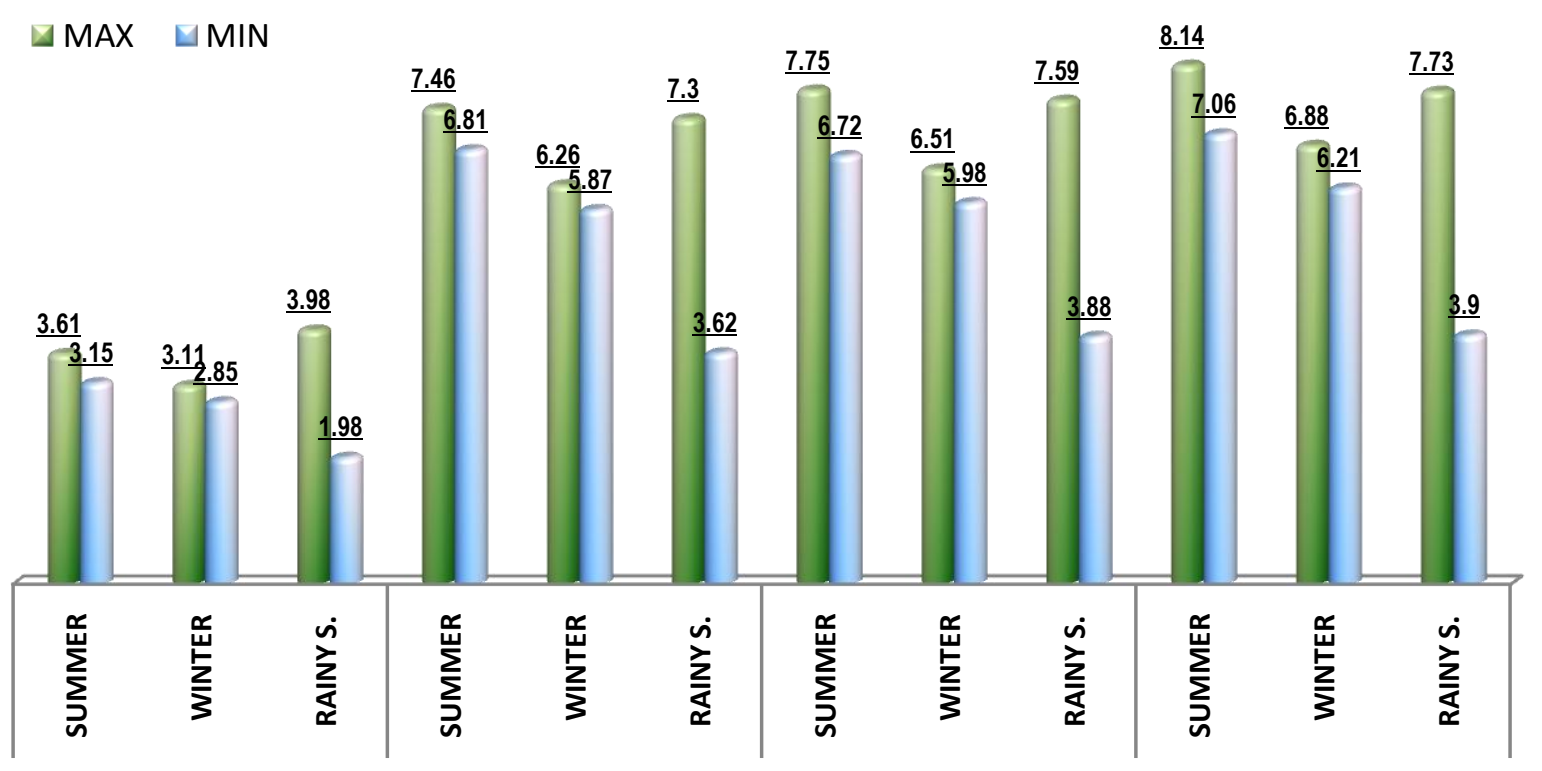

Fig-4 : Max. and Min. Levels of Nitrates (Mg/1) at Station S1,S2,S3\& S4 in Wainganga River

\section{Conclusion:}

As a result of present study, it is concluded that, the concentration of nitrates remains maximum during summer season and moderate during winter and rainy season. The proteinaceous organic matter present in municipal sewage and other wastes, on decomposition results in to the formation of ammonia. The increased activity of nitrifying bacteria in high temperature of river water causes the increase in the values of nitrates during summer season. Due to discharge of sewage and domestic wastes and less flow of water in the river results in to the turbidity. This may influence some extent, to the photosynthetic activities and up take of nutrients by phytoplanktons. To minimize the pollution of water and for improvement of its portability, the following measures are suggested, which may reduce the stress of pollutants in river water and subsequently controls the effect of pollution on human beings. 1). At station S-3 and S-4, the intensity of human activities can be reduced by providing the appropriate water supply to whole Pauni town in order to minimize their visit to the river for such daily needs. The more bore wells should be provided in the localities. 2). Pollution due to agricultural activity can be prevented on 
Government level, by providing substitute empty land to the farmers. The excess use of chemical nitrogenous fertilizers may be banned by periodical monitoring of trace nitrogen in the yields of rice fields located in the catchment areas. 3). The station of S-4 of a river is mostly affected by cremation activities. There should be separate and another place for cremation and post cremation religious activities. 4). In Pauni town several temples are located from which the decaying flowers and leaves are discharged in river water. Preparation of separate wells for discharge of such wastes by Municipal Corporation may help to reduce the stress of these wastes on river. 4). Peoples should avoid exposure to water, soil, or food contaminated with high levels of nitrates and nitrites and also should monitor the water closely.

\section{Acknowledgement:}

Author is thankful to Dr. P.G. Puranik, Ex.Principal and Ex. Head dept. of zoology D'Peth and M.P. Deo memorial science college, Nagpur, for his kind guidance and untiring help during the experimental work. Thankfulness is also due to Dr. Pravin Charde former principal, Sevadal Mahila Mahavidyalaya, for is help during experimentation and made available the research lab.

\section{References:}

Agency for Toxic Substances and Disease Registry (ATSDR), (2004). "Interaction Profile for: cyanide, fluoride, nitrate, and uranium". Atlanta, GA: US Department of Public Health and Human Services, Public Health Service.

Aggarwal T. R., Singh K. N. and Gupta A. K., (2000). "Impact of sewage containing domestic wastes and heavy metals on the chemistry of Varuna river water". Poll. Res. 19, (3) : 491-494.

Balls P. W., Brockie N. Dobson J. and Johnston W., (1996). "Dissolved oxygen and nitrification in the upper forth estuary during summer Patterns and trends". Life sciences 1996-1998". Ecology abstractssion No. 3873650.

Bobdey A.D., Bhagat V.B, Meshram C.B. \& Dhande R.S., (2009). "Trophic status of Ambadi dam in relation to physico chemical characteristics of its water". Biosci. Biotech. Res. Comm., Vol (2), No (2), 214-216.

Jameel Abdul A. (1998). "Physico-chemical studies in Uyyakondan channel water of river Cauvery".Poll. Res. 17, (2) : 118-114. 
Musaddiq M. (2000). "Surface water quality of Morna river at Akola". Poll. Res. 19, (4) : 685-691.

Narayan S. and Chauhan R. (2000). "Water quality status of river complex Yamuna at Panchnada (Distt.:Etawah, U.P., India)". I : An integrated management approach. Poll. Res. 19, (3) : 357-364.

Nathan D.M., Siegel A.J., Bunn H.F., (1977). "Acute methemoglobinemia and hemolytic anemia with phenazopyridine". Arch Intern ed;137(11):163638.

NEERI (1986). "Manual On Water And Waste Water Analysis". National Environmental Engineering Research Institutte, Nehru marg, Nagpur, India.

Prasanthan V. and Vasudevan Nayar T. (2000). "Impact assessmenthydrological studies on Parvaphyputhen AR". Poll. Res. 19, (3) : 475-479.

Rath P., Bhatta D., Sahoo B. N. and Panda U. C. (2000). "Multivariate statistical approach to study physico-chemical characteristics in NandiraBrahmani river, Angul-Talcher Belt, Orissa, India”. Poll. Res. 19, (4) : 701 710.

Sharma S. D. and Pande K. S. (1998). "Pollution studies on Ranganga river at Moradabad-Physico-chemical characteristics and toxic metals". Poll. Res. $17,(2): 201-209$.

Thomas S., Harikrishnan K., George S., Paulmurugan R. and Das M. R. (2001). "Studies on the water quality of Kuttanad Wetland ecosystem Kerala”. Poll. Res. 20, (1) : 59-66. 